Journal of Engineering and Applied Sciences 14 (Special Issue 7): 10033-10039, 2019

ISSN: 1816-949X

(C) Medwell Journals, 2019

\title{
Economic Democracy in New Competition (A Study of Law No. 5 of 1999 Concerning Prohibition of Monopolistic Practices and Unfair Business Competition)
}

\author{
Sri Widiyastuti, Moch. Najib Imanullah and Yudho Taruno Muryanto \\ Program in Law, Faculty of Law, Sebelas Maret University, Surakarta, Indonesia
}

\begin{abstract}
The development of information technology has resulted major changes in the form of business and its competition. Meanwhile, the principle of economic democracy has a different emphasis in its application to Law No. 5 of 1999 concerning prohibition of monopolistic practices and unfair business competition (Antimonopoly Law) with the 1945 Constitution of the Republic of Indonesia (UUD 1945) post amendment, so that, the law enforcement process cannot fulfill the sense of justice. This study discusses the principle of economic democracy which is an abstraction of the values of Pancasila and the 1945 Constitution which form the basis of the legal politics of the Indonesian economic system to answer legal issues concerning the relevance of the task rules and functions of the Business Competition Supervisory Commission (KPPU) with the business competition conditions of the digital economy age and how it applies to the context of the digital age. The research method used is doctrinal research that examines secondary data in the form of library materials covering primary, secondary and tertiary legal materials. The approach used is the legislative approach and the method of qualitative analysis with grammatical, systematic and theological interpretations. The results of the study show that the rules regarding the duties and functions of the Business Competition Supervisory Commission (KPPU) are irrelevant to be used as an instrument of prevention and enforcement of monopolistic practices and unfair business competition in the digital economy age, its caused they are not adjusted to the values of Pancasila and the 1945 Constitution. Economic democracy in accordance with current conditions of competition is a change in the principle and the objectives of the Antimonopoly Law in accordance with the emphasis of the principles of post-amendment economic democracy, along with the material on its body in the form of preventive and repressive rules based on the values of Pancasila and the 1945 Constitution.
\end{abstract}

Key words: Economic democracy, Law No. 5 of 1999, antimonopoly, UUD 1945, KPPU, business

\section{INTRODUCTION}

The rapid progress of Information and Communication Technology (ICT) or better known as information and technology (science and technology) has resulted in a drastic change in the trading model and business activities from conventional to digital, so that, ICT can be said to have revolutionized (Pramono, 2001) trade and business to digital economy age. The positive impact of this digital age is that there is an opportunity for global market expansion because the digital age has made borderless borders. Meanwhile, the negative impact is the emergence of a new competition model both because of the different business models (conventional business competition against digital business) and digital characteristics that make the market scope wider.

The concrete thing that can be used as an illustration is the case of Grab's acquisition (BISNIS, 2018) of Uber's assets (Goode, 2011). Grab will integrate the business of Uber's food and messaging service between
Southeast Asia to the multi-mode and fintech transportation platforms that Grab already has. Through this business combination, Grab will become No. 1 Online-to-Offline (O2O) mobile platform in Southeast Asia and become a major player in food-delivery messaging service (Goode, 2011). This is feared to lead to unhealthy competition patterns in transportation business in Indonesia. Another example is the conflict phenomenon between conventional taxi business and online taxis some time ago, proves that business competition in this digital age is getting tighter or more competitive. Conventional transportation has had a mandatory and legality before operating from the beginning with various licensing processes which require a lot of cost but the income earned continues to decline, even some public transports experience bankruptcy in the presence of online transportation modes.

Law No. 5 year 1999 concerning prohibition of monopolistic practices and unfair business competition (Antimonopoly Law) is a state instrument to create a

Corresponding Author: Sri Widiyastuti, Program in Law, Faculty of Law, Sebelas Maret University, Surakarta, Indonesia 10033 
conducive business climate in the structure of economic democracy where every citizen has the opportunity to participate in the production and marketing process of goods and or services in a healthy, effective and efficient business climate, so, it can encourage the economic growth and the operation of a fair market economy.

The facts described above show the opposite when it is associated with the economic democracy which becomes the principle of the Antimonopoly Law where each citizen participates in the production and marketing of goods and/or services process in a healthy business climate. There is a condition of unfair competition between conventional and digital business actors.

Problem statement: Economic democracy is a principle in carrying out economic activities in Indonesia. The foundation of this is found in the basic of the constitution, the 1945 Constitution of the Republic of Indonesia (Anonymous, 1945). It comes from the values of Pancasila which are socio-culturally "geis tiges kapital" or invaluable in encouraging the increased development. These values are firmly rooted in Indonesian culture at every stage of economic activity whether in production, distribution or consumption and they are important aspects in promoting development progress (Mubyarto dan Boediono, 1991).

However, the problem arises when there is a difference in emphasizing the use of the principle of economic democracy between the 1945 Constitution amendments to the Antimonopoly Law. The Antimonopoly Law emphasizes the balance between the interests of business actors and the public interest while the 1945 Constitution amendments emphasize the balance of progress and unity of the national economy. Considering that the principle is the basic thought behind the existence of concrete regulations which are validating and having the influence of binding power (Mertokusumo, 2009) the discrepancy of its application in the rule of law will result in its effectiveness in the field. The digital age makes business and trade activities faced with new forms of business competition that must be accommodated in its legal rules, so, it is very important to discuss the principle of law in the rules of legal business competition in order to understand the direction of legal ideals, especially, to face new competition in the digital economy age.

Research objectives: This study will discuss the principles of economic democracy as the legal politics of the Indonesian economic system related to its relevance to the advancement of ICT which revolutionizes the field of commerce and business into the digital economy age where in addition to changes in business models, it also changes the business competition models. This study is very important considering that there is a different emphasis on the principle of economic democracy between the 1945 Constitution post amendment to Law No. 5 of 1999 concerning prohibition of monopolistic practices and unfair business competition (Antimonopoly Law). Therefore, the issues raised are as follows:

- Are the KPPU's duties and functions still relevant as an instrument of prevention and enforcement of monopolistic practices and unfair business competition in the digital economy age?

- How is the appropriate application of the principles of economic democracy in facing the business competition in this digital age?

Theoretically, the results of this study will be useful for the repertoire of science (especially, those related to legal business competition and economic) and can practically be used as a scientific study material for the development of legal business competition in Indonesia.

\section{Literature review}

Economic democracy: The legal politics of the Indonesian economic system is seen in the formulation of Article 33 of the 1945 Constitution. It is full of the values of the philosophy of Pancasila as a view of the life of the Indonesian people which was formally stated in the opening of the 1945 Constitution. Figure such as Emil Salim, Mubyarto and Sumitro Djojohadikusumo describe Pancasila ideology through the details of the Pancasila moral principles in economy and business world (Sulistiyono and Muhammad Rustamji, 2009) which in general contain the following thread: the first moral principal, the Belief in the one and only God is a moral aspect in business and economic activities where there is an effort to balance material elements and spiritual elements or spiritual values.

The second moral principle, just and civilized humanity is an affirmation that business activities have a social and humanitarian dimension, it means that activities in which they are identical to seeking profit are also aimed at achieving equity (mutual prosperity). The third moral principle, the unity of Indonesia is an element of nationalism in the conduct of business activities where the activities and patterns of economic policy always prioritize the unity and unity of Indonesia.

The fourth moral principle, democracy guided by the inner wisdom in the unanimity arising out of deliberations amongst representatives is an opportunity for community participation in the development activities where Emil Salim refers to the implementation of economic and political democracy while Mubyarto calls the recognition of the existence of cooperatives. 


\section{J. Eng. Applied Sci., 14 (Special Issue 7): 10033-10039, 2019}

The fifth moral principle, social justice for all Indonesians is the basis for legal economic policy that is equitable development. If you look closely at the moral principles in Pancasila, the formulation of the sentence contains values that are quite universal (divinity, morality and humanity), so that, the provisions of Article 33 of the 1945 Constitution are very suitable to be used as the basis of Indonesia's economic system and are seen as an economic basis for community relations (Sulistiyono and Rustamji, 2009).

Evidence that the provisions of Article 33 of the 1945 Constitution animate the values of Pancasila is to decipher every single the paragraph of the article. Paragraph (1) states "The economy is structured as a joint venture based on the principle of kinship.” This article has the meaning that the Indonesian economic resurgence does not lie in the activities or individual movements but it is lying in a joint (structured) business where the outlook is not private prosperity but mutual prosperity. Paragraph (2) states "Production branches that are important to the state and which control the livelihood of the public shall be controlled by the state." Subsequently paragraph (3) explains that "The Earth, water and the wealth contained therein are controlled by the state and used for the greatest prosperity of the people.” Paragraphs (2) and (3) explain the difference between Indonesia's economic system and the economic system adopted by other countries. It is an important production factors placed on state control, not on individuals or private control.

In the explanation section of the 1945 Constitution (before the amendment), it was explained that economic democracy is an economic governance carried out by all elements of society, for the common purpose under the ruler or the representative. The aim to be achieved is not prosperity of a handful of people but mutual prosperity. It was emphasized that even though the production sector was carried out jointly with the aim of achieving mutual prosperity, the private sector was not allowed to manage strategic activities related to the livelihood of many people. In other words, the fields related to the lives of many people must absolutely be controlled by the state. Looking at these articles, it is clear that the legal policy of the Indonesian economic system is in the framework of a large welfare state.

After the amendment process, the provisions of Article 33 get two additional paragraphs that is Paragraph (4) elaboration of economic democracy, namely "National economy is organized based on economic democracy with the principles of togetherness, fairness efficiency, sustainable, environmentally sound and by maintaining the balance of progress and national economic unity." Paragraph (5) confirms that the regulation on economic democracy will be carried out by law. Part of the explanation of the 1945 Constitution and the formulation of Article 33 Paragraph (4) after the amendment in the reformation period, confirms that the people have sovereignty over the economic and political fields whose control and management are represented to the stat (Asshiddiqie, 2010).

Economic democracy as a whole is not interpreted as an equitable condition that applies the principle of equality (equal treatment) absolutely. Indonesian democracy aspires to realize social justice for all Indonesian people (social justice, fairness, equality), so that, it has a partiality to the weak, poor and underdeveloped to get special attention and treatment towards empowerment. This is not a negative thing but it is a manifestation of the principle of togetherness and kinship. That is this re-emphasizes that the principle of efficiency in economic democracy has a social dimension (Soekanto, 2006).

In fact, the term efficiency creates a negative interpretation because it is commonly used as a free market instrument in an effort to maximize production. With its replacement being a term of equitable efficiency, it signifies that there is a spirit of economic system transformation, considering that so far the practice of the Indonesian economy has been very monopolistic which is dominated by a handful of business elite who are close to power (Anonymous, 1999). The value imposed is moral and social responsibility, so that, this economic system can be called a social market economy. In other words, this economic structure empowers all economic actors in a balanced and sustainable manner towards quality economic growth, namely economic growth that guarantees fair equity (Soekanto, 2006).

Law No. 5 year 1999: In order to regulate business competition, the government enacted Law No. 5 of 1999 concerning prohibition of monopolistic practices and unfair business competition (Antimonopoly Law). In the general section the explanation of the law states that economic development and globalization are still major challenges faced by the government. Inaccurate policy measures cause the market to experience distortion as well as conditions of unfair business competition that occur in Indonesia where the implementation of the national economy does not refer to the mandate of Article 33 of the 1945 Constitution and tends to show a very monopolistic pattern, into several consideration of the issuance of this law.

This law intends to provide legal certainty to further encourage the acceleration of economic development as an effort to improve public welfare as well as the implementation of the spirit and soul of the 1945 Constitution. In the consideration stated that the reference of this law is Article 33 of the 1945 Constitution. 


\section{J. Eng. Applied Sci., 14 (Special Issue 7): 10033-10039, 2019}

However, the embodiment of the body of Law No. 5 of 1999 looks similar as the regulation of business competition in other countries. This suggests that Law No. 5 of 1999 was formed in a hurry to fulfill the demands of the International Monetary Fund (IMF) as part of the Letter of Intent (LOI) (Suhara, 2009). That is this law has not been able to elaborate further on the economic system in a juridical-philosophical manner applied in Indonesia.

From these facts, it can be concluded that this antimonopoly law has the spirit of the 1945 Constitution but its substance is capitalistic. Looking at the conditions of business competition in this digital economy age, a strategy for applying the principles of economic democracy is needed, so that, the rule of law can be formulated according to the cultural values of the Indonesian people and precisely in accordance with the context of its era.

The role of the business competition supervisory commission (KPPU): The implementation of the Antimonopoly Law is very juridical because this act safeguards to form an independent institution outside the government structure that can be free from the influence of power in carrying out supervision and action in the field of business competition. Therefore, the government issued a Presidential Decree (Keppres) No. 75 of 1999 concerning the Business Competition Supervisory Commission (KPPU) as a follow-up to Article 30 of the Antimonopoly Law where the purpose was to oversee the implementation of the Antimonopoly Law.

When observing Article 35 and 36 of the Antimonopoly Law which also regulates the duties and authorities of KPPU, KPPU's duties and authorities are an integrated activity series. Meanwhile, in terms of authority, KPPU is similar to Japan Fair Trade Commission (JFTC) which has three authorities at once, namely administrative authority (administrative power), authority to issue regulations (quasi-legislative power) (Anggara, 2009), authority to conduct researches and investigations and authority to impose sanctions (quasijudicial power) (Muwahid, 2015). However, in execution implementation, KPPU does not have any forced power as the judiciary; therefore, the KPPU still needs to strengthen the decision of the district court, so that, it can be carried out (Anonymous, 1999). The Indonesian justice system is only familiar with four judicial board; they are general, religious, military and state administration courts. Viewed from these four judicial boards, the KPPU is a special judicial institution which established under the environment of the general justice board. This can be seen from the mechanism of filing an objection to the KPPU's decision that must go through the district court (Anonymous, 1999). Therefore, from the constitutional aspect, KPPU only acts as an extension of the executive board (government). Although, it has the same authority as the authority of the judiciary (judicial institution), this authority is only apparent considering the sanctions imposed which are only administrative while investigating the criminal aspect is still on the authority of the district court.

\section{MATERIALS AND METHODS}

This research is a normative (doctrinal) legal research that examines the principles of economic democracy which are the basic principles of economic activity in Indonesia and their relevance to the development of ICT that changes business patterns and competition. This research is carried out with library research that is data search from various libraries related to the problem of the study through the approach of legislation (statue approach) (Ibrahim, 2007). The data needed are secondary data (Soekanto, 2006) consisting of primary legal material, namely binding legal material, terdiri dari bahan hukum primer, yaitu bahan hukum yang bersifat mengikat (Ashshofa, 2007) including the Constitution of the Republic of Indonesia of 1945, Law No. 5 of 1999 concerning prohibition of monopolistic practices and unfair business competition, Presidential Decree (Keppres) of the Republic of Indonesia No. 75 of 1999 concerning the Business Competition Supervisory Commission (KPPU) and other related laws and regulations. Then, secondary legal material is legal material that provides an explanation of primary legal materials (Aashshofa, 2007) which consists of various references to books, research results, scientific journals that are relevant to the object of this study. Meanwhile, tertiary legal material is a legal material that provides clarity of secondary legal material in the form of Indonesian Dictionary and Legal Dictionary (Black's Law Dictionary).

Data collectionis carried out by means of document/literature study which examines the data obtained in the form of library materials/documents that are relevant to the issues of the study. After processing the data collection, the next step is processing the data. The data is grouped and selected (sorted according to the relevance of the research object), then it was analyzed using qualitative methods that is the elaboration and discussion of research results based on legal norms, then it was interpreted using systematic, grammatical and theological interpretation methods (Asshiddiqie, 2010) to answer the problems in the research. 


\section{J. Eng. Applied Sci., 14 (Special Issue 7): 10033-10039, 2019}

\section{RESULTS AND DISCUSSION}

\section{Data analysis}

Relevance of the rules for the tasks and authority of KPPU with the digital age conditions and how to applicationed it: On the background of the problem it has been raised regarding the fact that there is a difference in emphasizing on the use of principles of economic democracy where the Antimonopoly Law emphasizes the balance between the interests of business actors and the public interest. Meanwhile, in the formulation of Article 33 of the 1945 Constitution the amendment shows that the emphasis is on the balance of progress and unity of the national economy.

The emphasis on the balance between business actors and the public interest of the legal basis is difficult to trace in fourth amendment of the 1945 Constitution at Chapter XIV. The definition of public interest that is very broad and is not included in the provisions of the body of the Antimonopoly Law causes multiple interpretations and it will continue to cause legal debate. The concept of public interest is defined by many experts and regulated in various laws and regulations with different meanings according to their designation (BISNIS, 2018). Seeing the broad meaning of this public interest, the concept of balance between business actors and the public interest in the Antimonopoly Law becomes uncertain (vague), so that, if we see the goal that is to protect consumers, then the interpretation becomes the same as the basic principles of American Antitrust Law. Thus, theologically, the meaning of balance in the Antimonopoly Law is the protection of the public interest that refers to the interests of consumers with efficiency is as a measure of business competition. Considering the principle is the heart of the law, it is the basic values that form a concrete regulation, so, it can be concluded that this Antimonopoly Law is not from the 1945 Constitution and the values of Pancasila, so that, the substance is not in accordance with the 1945 Constitution and the value of Pancasila.

In connection with the responsive legal concept developed by Philippe Nonet and Philip Selznick which in essence emphasizes that legal norms are not autonomous, they are very dependent on the reality of society through their dynamics (Nonet and Selznick, 1978) the Antimonopoly Law must have a catching power on the dynamics of community needs. This community need is a new form of business and competition which is caused by digital economic phenomena which demand to be accommodated in legal norms. In responsive legal concepts, Nonet and Selznick pay special attention to variables related to law, namely the role of coercion in law, the relationship between law and politics, the state, moral order, place of discretion, role of goals in legal decisions, participation, legitimacy and conditions of compliance with the law (Nonet and Selznick, 1978).
It means, the rule of law that seeks to accommodate progress is ideally formulated according to the moral order that is believed by the Indonesian people. Typical of responsive law that distinguishes it from the autonomous legal concept lies in its purpose which is not just the creation and application of law but a broader social interest. However, the purpose of law and the social interests that must be served are not always apparent, it is implicit. So, the most important thing is the elaboration of what purpose, value and interests must be at stake to clarify the purpose of the law. Nonet and Selznick illustrate it as a law that is flexible and contextual (Fadjar, 2013).

In the writer understanding, the digital economics age that changes the business and competition model, the responsive concept should be seen from the efforts to establish laws that are in accordance with the context of Indonesian values. Every country in this world experiences what is called economic globalization but although, they have the same problems it does not necessarily make them need a way to solve the same problem because each country has a different social culture. Presumably, this is in accordance with Von Savigny's understanding that the law is not made but grows and develops in the nation's soul (volkgeist). He was very dynamic following the spirit and soul of the nation.

The context of competition in the digital age, the rules regarding the duties and functions of KPPU are irrelevant to be used as an instrument of prevention and enforcement of monopolistic practices and unfair business competition because the principles and objectives formulated in the Antimonopoly Law are not in accordance with the formulation of the principles of economic democracy in the 1945 Constitution post amendment. The spirit of law enforcement is not based on the values of Pancasila and the 1945 Constitution.

So, the value underlying the concept of national economic unity is the value of social justice as formulated in chapter XIV of the 1945 Constitution entitled national economy and social welfare. The meaning of the title formula is that the implementation of the national economy must lead to the order of people's welfare. Concretely, it can be explained by the rules of prevention and repression of monopolistic practices and unfair business competition that are in accordance with the context of the Indonesian economy, namely the values of Pancasila (economic democracy regulated in the 1945 Constitution). The process of preventing monopolistic practices and unfair business competition is carried out by providing guarantees for equal opportunities for every business actor (small, medium and large) with instruments of fairness efficiency that is to keep in mind the ability of the business sector that is still weak has to be empowered, so that, all business actors can compete with the real entrepreneurial spirit. Meanwhile, 


\section{J. Eng. Applied Sci., 14 (Special Issue 7): 10033-10039, 2019}

the process of law enforcement is based on kinship as the spirit in the second principle of Pancasila, so that, the sanctioning process is placed as the last tool (Ultimum Remedium).

\section{CONCLUSION}

This study of the principles of economic democracy, elicits the original cultural values of the Indonesian people which form the basis of the philosophy of national economic activities. The fact that there are differences in emphasis in the application of the principle of economic democracy between Law No. 5 of 1999 concerning prohibition of monopolistic practices and unfair business competition (Antimonopoly Law) with the 1945 Constitution of the Republic of Indonesia (UUD 1945) post amendment behind the process of prevention and enforcement of monopolistic practices and unfair business competition in Indonesia. In this case, the elaboration of the broader interests of society in the frame of cultural culture is the basis for the formulation of the objectives of legal business competition. The aim was none other than the achievement of Indonesia's national objectives as stated in the preamble of the 1945 Constitution. The national objective was to protect the entire Indonesian nation and all of Indonesia's bloodshed, promote public welfare, educate the nation's life and carry out world order based on independence, eternal peace and social justice.

The concept of the balance of the progress and unity of the national economy in the 1945 Constitution version of the post-amendment economic democracy is a formula that translates the value of the nation's culture derived from the values of Pancasila as a state view of life. In responsive legal theory, the values and moral order become important things to be considered in the system of legal norms, to clarify its purpose. Therefore, the Indonesian economic legal system must pay attention to the application of its own cultural values that are in accordance with the method of its economy. So, it is impossible for a legal norm to achieve a goal clearly, if the spirit comes from another nation's value system.

This is the case with the Antimonopoly Law where the substance of the material is not imbued with cultural values derived from the Pancasila and the 1945 Constitution, so that, the law enforcement of business competition is far from the sense of Pancasila justice. Thus, so that, the rules regarding the duties and functions of KPPU in terms of prevention and enforcement of monopolistic practices and unfair business competition are relevant to the competitive conditions of the digital economy age, then it must be adjusted to the values of Pancasila and the 1945 Constitution amendments.
Furthermore, the application of the principle of economic democracy which focuses on the balance of national economic progress and unity must be realized in concrete, clear and not multi-interpretive norms for not causing debate in achieving its legal objectives. Concretely, there must be a change in the formulation of Article 2 of the Antimonopoly Law on the principle and purpose which is adjusted to the emphasis of the principles of economic democracy of the post amendment. The formulation of the articles in the body of the Antimonopoly Law must reflect prevention and enforcement of monopolistic practices and unfair business competition. Prevention efforts are carried out by regulating guarantees for equal opportunities in business (equality with fair efficiency perspective), that is an effort to protect small and medium business sectors that still have low competitiveness to be fostered and empowered. Meanwhile, the process of law enforcement puts forward a family spirit which places sanctions as the last attempt (ultimum remedium).

\section{REFERENCES}

Anggara, S., 2009. Commission for the supervision of business competition and special justice (KPPU position in Law No. 4 of 2004 concerning judicial power). J. Bus. Competition, 2009: 165-168.

Anonymous, 1945. The 1945 Constitution of the Republic of Indonesia as amended by the first amendment of 1999, the second amendment of 2000, the third amendment of 2001 and the fourth amendment of 2002. Constitution of Indonesia, Indonesia. https://www.ilo.org/wcmsp5/groups/public/--ed_protect/---protrav/---ilo_aids/documents/ legaldocument/wcms_174556.pdf

Anonymous, 1999. Law of the Republic of Indonesia No. 5 year 1999 concerning the prohibition of monopolistic practices and unfair business competition. State Gazette of the Republic of Indonesia, Indonesia. https://www.wipo.int/edocs/ lexdocs/laws/en/id/id050en.pdf

Ashshofa, B., 2007. Legal Research Methods. Rineka Cipta, Jakarta, Indonesia, Pages: 103.

Asshiddiqie, J., 2010. [Economic Constitution]. PT Kompas Media Nusantara, Central Jakarta, Indonesia, ISBN:9789797094652, Pages: 441 (In Indonesian).

BISNIS, 2018. Grab merger with Uber in Southeast Asia. Bisnis Indonesia, Jakarta, Indonesia. (In Indonesian) https://www.grab.com/id/press/business/grab-mergerdengan-uber-di-asia-tenggara/

Fadjar, A.M., 2013. [Contemporary Legal Theories]. Setara Press, Malang, Java, Indonesia, Pages: 54 (In Indonesian). 
Goode, L., 2011. Worth it? An app to get a cab. Dow Jones \& Company, New York, USA. https://blogs.wsj.com/digits/2011/06/17/worth-it-anapp-to-get-a-cab/

Ibrahim, J., 2007. Normative Legal Theory, Methods and Research. Bayumedia Publishing, Malang, Java, Indonesia.

Mertokusumo, S., 2009. Discovery of Law: An Introduction. 2nd Edn., Penerbit Liberty, Yogyakarta, Indonesia.

Mubyarto and Boediono, 1991. Pancasila Economics. BPFE PT Penerbit \& Percetakan, Yogyakarta, Indonesia, Pages: 112.

Muwahid, 2015. [Juridical implications of the meaning of the meaning of general interests in land procurement law for development for general interest (In Indonesian)]. AL. Hikmah J. Islamic Stud., 5: 190-200.
Nonet, P. and P. Selznick, 1978. Law and Society in Transition: Toward Responsive Law. 1st Edn., Harper \& Row, New York, USA., ISBN:9780061319549, Pages: 122.

Pramono, N., 2001. [The revolution of the Indonesian business world through e-Commerce and e-Business: How is the legal solution (In Indonesian)]. J. Faculty Law UII, 8: 1-9.

Soekanto, S., 2006. [Introduction to Legal Research]. UI-Press, Central Jakarta, Indonesia, ISBN: 9789798034480, Pages: 277 (In Indonesian).

Suhara, J.J., 2009. Principle definition and purpose of Law No. 5 year 1999 as legal basis and business competition policy in Indonesia. J. Bus. Competition, 2009: 94-96.

Sulistiyono, A. and M. Rustamji, 2009. Law of Economics as Commander-in-Chief. PT. Masmedia Buana Pustaka, Sidoarjo, Indonesia. 